\title{
Bioelectrochemical Denitrification for the Treatment of Saltwater Recirculating Aquaculture Streams
}

\author{
Elisa Marx Sander, B Bernardino Virdis, and Stefano Freguia* \\ Advanced Water Management Centre, The University of Queensland, Level 4, Gehrmann Laboratories Building (60), Brisbane, QLD \\ 4072, Australia
}

\section{Supporting Information}

\begin{abstract}
Maintaining low concentrations of nitrogen compounds (ammonium, nitrate and nitrite) in recirculating aquaculture waters is extremely important for a larger and healthier fish production, as well as for water discharge purposes. Although ammonium removal from aquaculture streams is usually done within a nitrifying step, nitrate removal via denitrification is still partially limited by the low organic matter availability. Therefore, an easy-to-operate autotrophic denitrifying bioelectrochemical system is herein proposed for the treatment of seawater aquaculture streams. The nitratecontaining synthetic stream flows sequentially through a biological denitrifying cathode (placed at the lower portion of a tubular reactor) and an abiotic anode (generating

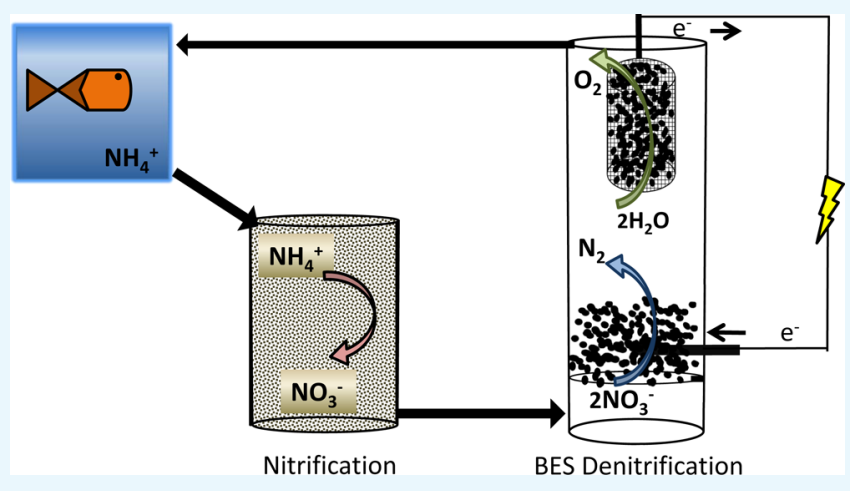
electrons and oxygen from water splitting, at the upper portion). Experimental results with synthetic seawater showed that the system reached denitrification rates of $0.13 \pm 0.01 \mathrm{~kg} \mathrm{~N} \mathrm{~m}^{-3} \mathrm{day}^{-1}$, operating with minimum ammonium and nitrite accumulation, as well as minimum chlorine formation in the abiotic anode, despite the high chloride concentration. There results support the technical potential for simultaneous bioelectrochemical denitrification and partial re-oxygenation of aquaculture waters either for recirculation or discharge purposes.
\end{abstract}

\section{INTRODUCTION}

Nitrogen accumulation represents an important factor contributing to water deterioration in recirculating aquaculture systems (RASs). Studies on nitrogen balances in aquaculture (which include a nitrifying biofilter) indicate that cultivated species assimilate only $25-40 \%$ of the nitrogen provided to the system as feed, ${ }^{1,2}$ whereas $30-40 \%$ is maintained as organic nitrogen in feces or unused feed and will remain in the sediment at the bottom of the tanks. ${ }^{3}$ The remain fraction of nitrogen (approximately 30\%) is usually excreted as ammonium, and it is further converted to nitrate $\left(\mathrm{NO}_{3}{ }^{-}\right){ }^{2,4}$ whereas 1.7 and $0.6 \%$ remain in the tanks as ammonium $\left(\mathrm{NH}_{4}^{+}\right)$and nitrite $\left(\mathrm{NO}_{2}{ }^{-}\right)$, respectively. ${ }^{2}$

Ammonium presents potential toxicity to aquatic species, as it is partially present in free ammonia form specially at high $\mathrm{pH}^{5}$ Because of that, nitrifying treatment units are usually installed in RAS, transforming the ammonium into less toxic nitrate, which may accumulate in concentrations as high as $\mathbf{5 0 0}$ $\mathrm{mg} \mathrm{L} \mathrm{L}^{-1} \mathrm{NO}_{3}{ }^{-}-\mathrm{N}$ at low water exchange rates. ${ }^{6}$ The accumulation of nitrite, a toxic nitrification intermediate, may also occur. ${ }^{5}$ Although nitrate is generally better tolerated by fish, its presence in concentrations higher than $125 \mathrm{mg} \mathrm{L}^{-1}$ $\mathrm{NO}_{3}{ }^{-}-\mathrm{N}$ may be harmful to the growth of some species such as turbot and prawns, especially during the initial stages of development. ${ }^{7,8}$ In addition, the Australian and New Zealand Guidelines for Fresh and Marine Water Quality ${ }^{9}$ suggest that nitrate concentrations in aquaculture systems should be lower than $50 \mathrm{mg} \mathrm{L}^{-1}$ for freshwater species and $100 \mathrm{mg} \mathrm{L}^{-1}$ for saltwater species. In summary, maintaining concentrations of nitrogen compounds below those values is extremely important for a larger and healthier fish production in RAS with a high recirculation rates. Furthermore, due to increasingly stricter environmental regulations worldwide, nitrate removal is also required before the discharge into natural ecosystems. As an example, the levels of $\mathrm{NO}_{x}\left(\mathrm{NO}_{3}-\mathrm{N}+\mathrm{NO}_{2}-\mathrm{N}\right)$ ranging from 1 to $30 \mu \mathrm{g} \mathrm{L}^{-1}$ are already considered sufficient to trigger slightly to moderate disturbance in the aquatic systems in some tropical areas of Australia. ${ }^{9}$ Those values are highly dependent on the level of environmental protection of the aquatic ecosystem and average rainfall, which may considerably influence licensed discharge limits, depending on the location of the aquaculture farm.

More recently, the installation of denitrification units has been proposed in RAS to reduce levels of nitrate in fish tanks ${ }^{10}$ and enable higher rates of water recirculation/reuse. Available technologies usually rely on heterotrophic microbial metabolism where addition of carbon sources (e.g., methanol) is done to guarantee sufficient $\mathrm{C} / \mathrm{N}$ ratio to achieve complete

Received: February 18, 2018

Accepted: March 27, 2018

Published: April 16, 2018 

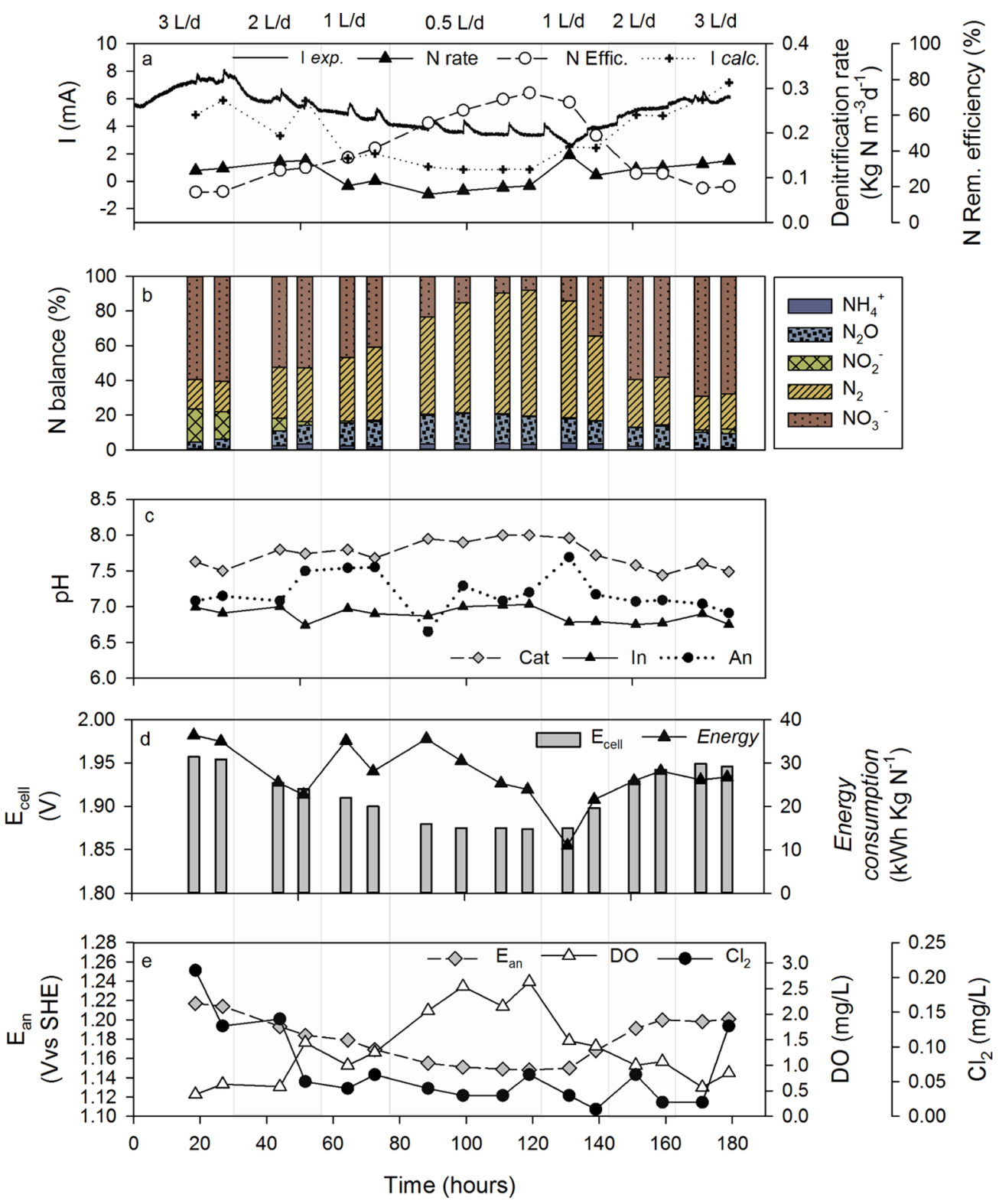

Figure 1. Reactor behavior during test 1 , carried out with the flow rates of 3, 2, 1, and $0.5 \mathrm{~L} \mathrm{day}^{-1}$ corresponding to 40, 60, 120, and $240 \mathrm{~min} \mathrm{HRT}$, respectively. (a) Experimental and calculated current production based on maximum buffer capacity (mA), nitrate removal rate via complete denitrification $\left(\mathrm{kg} \mathrm{NO}_{3}^{-}-\mathrm{N} \mathrm{m}^{-3}\right.$ day ${ }^{-1}$ ), and nitrogen removal efficiency (\%). (b) Nitrogen balance (\%) of all nitrate entering the system. $\mathrm{NO}_{3}^{-}-\mathrm{N}$, $\mathrm{N}_{2} \mathrm{O}-\mathrm{N}, \mathrm{NO}_{2}^{-}-\mathrm{N}$, and $\mathrm{NH}_{4}{ }^{+}-\mathrm{N}$ were measured from liquid samples, whereas $\mathrm{N}_{2}$ was assumed to be a result of complete denitrification and calculated as all unaccounted nitrogen in liquid samples. (c) The reactor $\mathrm{pH}$ profile at different sampling points: influent media, postcathode media, and postanode media leaving the system. (d) Cell voltage (V) and calculated energy consumption ( $\mathrm{kWh} \mathrm{kg} \mathrm{NO}_{3}^{-}-\mathrm{N}^{-1}$ ). (e) Anodic reactions: anodic potential $(\mathrm{V})$, dissolved oxygen $\left(\mathrm{mg} \mathrm{L}^{-1} \mathrm{O}_{2}\right)$, and free chlorine $\left(\mathrm{mg} \mathrm{L}^{-1} \mathrm{Cl}_{2}\right)$.

denitrification. However, the return of unused organic matter carried over from the denitrification unit to the aquaculture tanks may cause fish toxicity or the undesired growth of bacteria and further consumption of oxygen. In addition, it may lead to hypoxic conditions in the fish tank, potentially leading to death of farmed species if no further aeration/oxygenation is provided. Although methanol addition can be avoided by using endogenous carbon sources ${ }^{11}$ (which may require a predigestion of organic material eventually coming from the fish farm itself), the above issues may still occur. Alternatively, autotrophic bioreactors rely on chemolithotrophic microbial metabolism, using carbon dioxide as the carbon source and hydrogen gas as the energy source. Hydrogen can be introduced from a compressed gas cylinder or, alternatively, generated in situ at the cathode of a (bio)electrolytic cell. ${ }^{12,13}$ Because the latter process may use microorganisms to catalyze nitrate reduction at the biofilm-electrode interface, the process can be referred to as bioelectrochemical denitrification. ${ }^{14}$

In a typical bioelectrochemical system (BES) performing denitrification, electrons can be generated abiotically by electrolysis of water at the anode with simultaneous production of oxygen gas. ${ }^{15}$ The electrons generated from the oxygen evolution are then transferred to the cathode through an external circuitry where they are used for microbial-mediated denitrification either via direct electron transfer or via intermediate $\mathrm{H}_{2}$ production. Because the presence of dissolved oxygen (DO) is critical for fish respiration, the anodically 


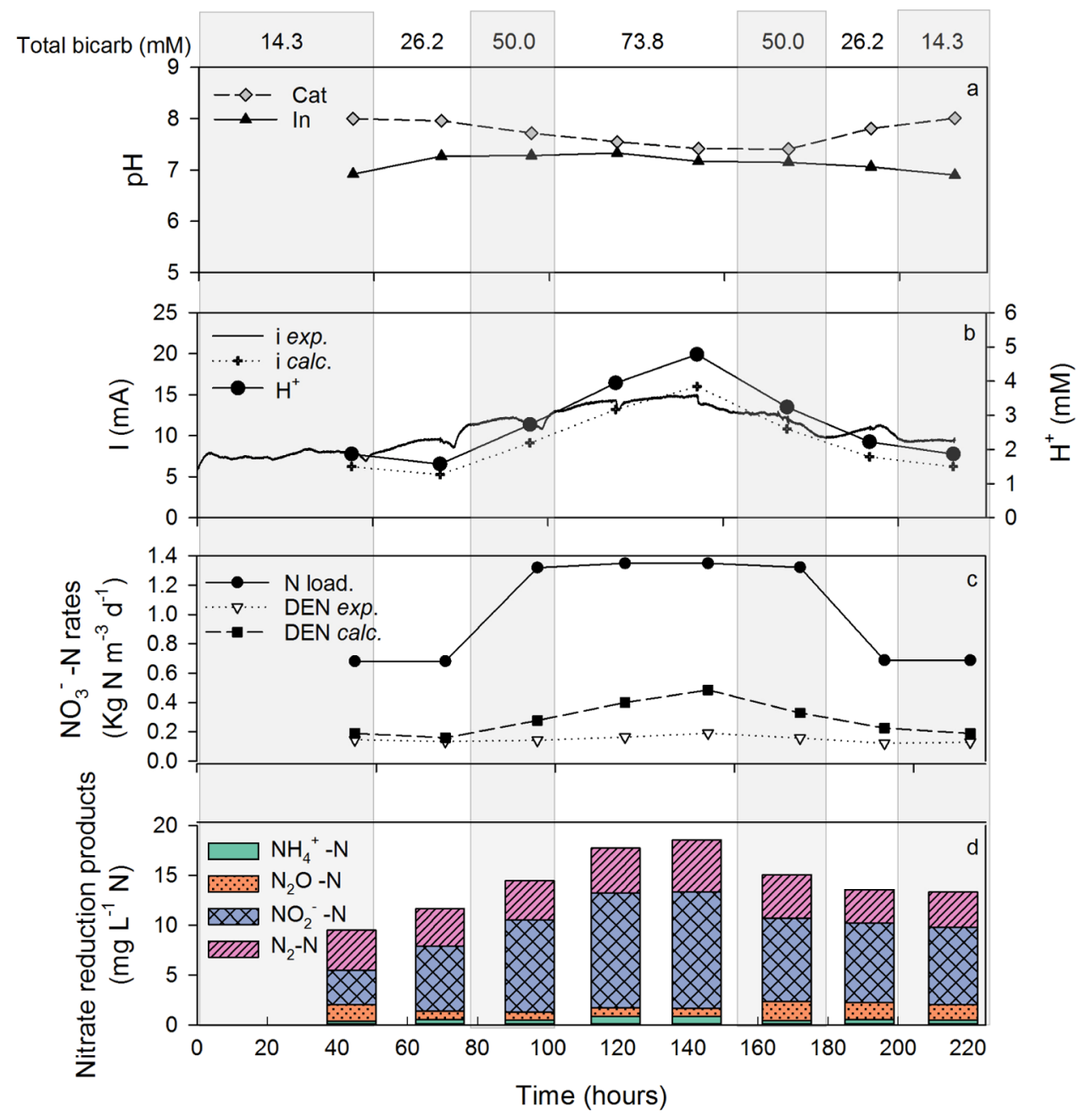

Figure 2. Effects of different buffer capacity concentrations. Tests were carried out with added concentrations of $1,2,4$, and $6 \mathrm{~g} \mathrm{~L}^{-1} \mathrm{NaHCO}_{3}$ (leading to total influent concentrations of $14.3,26.2,50.0$, and $73.8 \mathrm{mM}$, respectively). (a) $\mathrm{pH}$ profiles of the influent and cathodic effluent medium. (b) Experimental and calculated current production based on buffer capacity $(\mathrm{mA})$ and maximum proton availability from bicarbonate buffer system at the influent/effluent $\mathrm{pH}$. (c) Effective and expected denitrification rates and nitrate loading rate $\left(\mathrm{kg} \mathrm{NO}_{3}{ }^{-}-\mathrm{N} \mathrm{m}^{-3}\right.$ day $\left.{ }^{-1}\right)$. (d) Concentration of nitrate reduction products leaving the cathodic zone. The sum of all the products represents the total nitrate reduced in the system.

generated oxygen is desirable and beneficial in maintaining adequate oxygen levels in the aquaculture tanks.

Although various examples of applications of BES technology to treat nitrate-contaminated water streams are presented in the scientific literature (e.g., in the fields of wastewater and groundwater treatment), ${ }^{16-19}$ to our best knowledge, there are currently no studies available demonstrating the bioelectrochemical denitrification in seawater streams commonly used in aquaculture. Therefore, this work focuses on developing an easy-to-operate system able to achieve autotrophic bioelectrochemical denitrification, potentially providing a useful oxygenation step of the treated effluent. By systematically studying the variations in flow rate, buffer concentration and mixing condition, we aim to identify the system's rate-limiting steps (i.e., nitrate availability, buffer availability, ion transfer between cathode and anode or mass transfer at biofilm/ electrolyte interface) and maximize the reactor's performance.

\section{RESULTS AND DISCUSSION}

Tests at Different Influent Flow Rates. Liquid samples during test 1 were taken twice at each flow rate, and in each direction of the test (increasing/decreasing flow rate), totaling four replicates. Therefore, averages and standard deviations presented herein were obtained for the four replicate samples, unless stated otherwise (Figure 1).

The electric current reaches a maximum of $7.2 \mathrm{~mA}$ at the beginning of the first run at the flow rate of $3 \mathrm{~L} \mathrm{day}^{-1}$, then decreases to a minimum of $3.9 \mathrm{~mA}$ at the flow rate of $0.5 \mathrm{~L}$ day $^{-1}$ (Figure 1a). A further decrease in current is observed when the flow rate is $1 \mathrm{~L} \mathrm{day}^{-1}$, likely due to air intrusion when previously replacing the feed reservoir, which possibly leads to a temporary and unusual mixing/hydraulic condition (i.e., hydraulic retention time (HRT)) before this specific sample-also possibly leading to a mismatched nitrate concentration. Similarly, slight variations in the current profiles were produced each time a liquid sample was taken just above the cathode area.

Nitrogen removal rate is at its maximum at 2 and $3 \mathrm{~L} \mathrm{day}^{-1}$ $\left(0.13 \pm 0.01 \mathrm{~kg} \mathrm{~N} \mathrm{~m}^{-3}\right.$ day $^{-1}$, with no significant difference between these two flow rates; $P=0.70$ ) and decreases to 0.07 $\pm 0.01 \mathrm{~kg} \mathrm{~N} \mathrm{~m}^{-3} \mathrm{day}^{-1}$ at $0.5 \mathrm{~L} \mathrm{day}^{-1}$ (Figure 1a). These nitrogen-removal rates are within the ranges previously reported for bioelectrochemical denitrification $(0.05-0.41 \mathrm{~kg}$ 
$\mathrm{N} \mathrm{m}^{-3}$ day $\left.^{-1}\right),{ }^{14,18,20}$ which proves the proposed setup as a viable system for nitrate removal from saltwater streams.

Although better nitrogen removal rates is observed at $3 \mathrm{~L}$ day $^{-1}\left(0.7 \mathrm{~kg} \mathrm{~N} \mathrm{~m}^{-3}\right.$ day $^{-1}$ loading rate), only less than $20 \%$ of $\mathrm{NO}_{3}{ }^{-}-\mathrm{N}$ is completely removed as $\mathrm{N}_{2}$ (Figure $1 \mathrm{~b}$ ), indicating that lower nitrate loading rates of 0.11 and $0.23 \mathrm{~kg} \mathrm{~N} \mathrm{~m}^{-3} \mathrm{day}^{-1}$ are best suited for this purpose. In fact, best nitrate removal efficiencies and minimum nitrite accumulation are achieved at these lower loading rates. The accumulation of nitrate and nitrite at the fast flow rate indicates that the nitrate-loading rate is not the rate-limiting step of the process.

Although sulfate was also present in the artificial saltwater media, its theoretical redox potential $\left(E^{0 \prime}=-0.213 \mathrm{~V}\right.$ vs standard hydrogen electrode $(\mathrm{SHE}))^{21}$ is much lower than that of nitrate $\left(E^{0 \prime}=+0.43 \mathrm{~V}\right.$ vs SHE $),{ }^{22}$ which indicates that nitrate is a much preferable electron acceptor than sulfate. Thus, considering that nitrate was still present in the reactor at all times, sulfur reduction was neglected. Minteq simulations indicated that approximately $10-18 \%$ of the added sodium bicarbonate is expected in acid form $\left(\mathrm{CO}_{2}\right)$, and these values were strongly affected even by small variations within the influent $\mathrm{pH}$. After passing through the cathodic zone, the $\mathrm{pH}$ increases immediately from the neutral values of the feed (Figure 1c), and this variation is inversely associated to the flow rate, reaching $8.0 \pm 0.1$ at the lowest flow rate of $0.5 \mathrm{~L} \mathrm{day}^{-1}$. After the anodic zone, the $\mathrm{pH}$ tends again toward neutral values $(7.2 \pm 0.3)$ due to anodic oxygen evolution reaction, which consumes alkalinity. However, only a maximum of $1 \%$ of the bicarbonate system is predicted to be present as $\mathrm{CO}_{3}{ }^{2-}$ at the measured effluent $\mathrm{pH}$, indicating that only a negligible buffer capacity is provided by protons coming from $\mathrm{HCO}_{3}{ }^{-}$to form $\mathrm{CO}_{3}{ }^{2-}$. Interestingly, the estimated current generation is lower than that obtained experimentally, but follows a similar trend at all times (Figure 1a), indicating that the effective buffer capacity is strongly linked to the system's performance. These results also suggest a depletion of buffer capacity (proton availability from bicarbonate system), in which consumption of protons coming from water splitting rather than from $\mathrm{CO}_{2}$ (which led to $\mathrm{pH}$ rise) could allow a higher current generation than originally predicted. Alternatively, it is also possible that other (unaccounted) buffer species are also present or that slightly inaccurate $\mathrm{pK}$ values of the bicarbonate buffer were predicted by the model.

The measured anodic potential shows a positive correlation with $\mathrm{Cl}_{2}$ concentration (Figure 1e). However, the measured potentials are relatively constant at all times $(+1.18 \pm 0.02 \mathrm{~V}$ vs SHE) and lower than the standard redox potential for $\mathrm{Cl}_{2}$ formation $\left(E^{0 \prime}=+1.36 \mathrm{~V}\right.$ vs SHE $){ }^{23}$ which explains the very low concentration of $\mathrm{Cl}_{2}$ detected in the effluent $(0.07 \pm 0.06$ $\mathrm{mg} \mathrm{L}{ }^{-1} \mathrm{Cl}_{2}$, which is very close to the lower detection limit of the method, despite the very high concentration of sea salt of prepared artificial media). Although chloramine formation is also possible in the system, only negligible amounts can be expected due to the low concentration of free ammonia (less than $2 \%$ of total ammonium at $\mathrm{pH} 7.5$, corresponding to 0.003 $\mathrm{mM} \mathrm{NH}_{3}$ in our system). In addition, as shown in Figure 1e, only less than $0.2 \mathrm{mg} \mathrm{L}^{-1} \mathrm{Cl}_{2}(0.0056 \mathrm{mM} \mathrm{Cl})$ was detected in the reactor effluent at all times. Thus, considering the required ratio of $1: 1(\mathrm{~N} / \mathrm{Cl})$, chloramine formation would be limited by the amount of free ammonia in our system. Moreover, chloramine is a milder disinfectant than free chlorine itself.

Although the measured DO is also very low $(1.3 \pm 0.7 \mathrm{mg}$ $\mathrm{L}^{-1} \mathrm{O}_{2}$ ), the measured anode potentials are higher than the standard potential for $\mathrm{O}_{2}$ formation $\left(E^{0 \prime}=+0.82 \mathrm{~V}\right.$ vs SHE$){ }^{22}$ It is possible that bubbles formation may reduce the transfer rates of $\mathrm{O}_{2}$ between the electrode (at formation points) and the liquid phase, which corroborates with a slightly larger dissolved oxygen concentration at smaller flow rates: longer HRTs would enable higher transfer of oxygen from bubbles (formed at anode) toward the liquid phase. Therefore, further improvement in electrode configuration and mixing regimes enabling better transfer of oxygen to liquid phase are encouraged.

Effect of Electrolyte Buffer Capacity. Although $\mathrm{pH}$ and buffer capacity of synthetic media normally tested in BES systems are well known to influence reactors performance, ${ }^{24-27}$ the variability of media composition on the effective buffer capacity has not been evaluated so far. When applying only $1 \mathrm{~g}$ $\mathrm{L}^{-1} \mathrm{NaHCO}_{3}$, the $\mathrm{pH}$ increases from $6.91 \pm 0.01$ (inflow media) to $8.01 \pm 0.01$ (outflow right after the cathode). However, the $\mathrm{pH}$ increases from only $7.3 \pm 0.1$ to $7.5 \pm 0.1$ when $6 \mathrm{~g} \mathrm{~L}^{-1} \mathrm{NaHCO}_{3}$ was tested (Figure 2a). Based on the $\mathrm{pH}$ measurements shown in Figure $2 \mathrm{a}$ and known concentration of major ions in prepared media, the proton availability (i.e., $\mathrm{mM} \mathrm{H}^{+}$) and expected current production are calculated as shown in Figure $2 \mathrm{~b}$. Although the buffer capacity increases with the addition of bicarbonate, the Minteq simulations indicate that bicarbonate speciation and effective concentration of proton equivalents in the saltwater medium are strongly dependent on the $\mathrm{pH}$. As indicated, the added bicarbonate increases by a factor of 6 , whereas the effective buffer capacity only doubles due to the slightly higher feed $\mathrm{pH}$ when $6 \mathrm{~g}$ $\mathrm{L}^{-1}$ sodium bicarbonate was added.

The effective current generation is in fact slightly higher than predicted, which reflects bigger $\mathrm{pH}$ changes between inflow and outflow upon small additions of sodium bicarbonate, corroborating the tests at different flow rates. However, predicted and effective current values tend to match more closely at higher bicarbonate additions, and a minimum $\mathrm{pH}$ change is observed when adding $6 \mathrm{~g} \mathrm{~L}^{-1}$ sodium bicarbonate.

The increase in sodium bicarbonate concentration (from 1 to $6 \mathrm{~g} \mathrm{~L}^{-1} \mathrm{NaHCO}_{3}$ ) also leads to an increase in the denitrification rates from $0.14 \pm 0.01$ to $0.18 \pm 0.02 \mathrm{~kg} \mathrm{~N} \mathrm{~m}^{-3}$ day $^{-1}$, respectively (Figure 2c). However, the effective denitrification rates are smaller than expected at the maximum added buffer capacity, as a result of a bigger nitrite accumulation (Figure $2 \mathrm{~d}$ ). In addition, a slightly smaller Coulombic efficiency (CE) occurred when adding $6 \mathrm{~g} \mathrm{~L}^{-1}$ sodium bicarbonate (90.8 \pm $1.5 \%$, compared to $105.1 \pm 0.2$ at $1 \mathrm{~g} \mathrm{~L}^{-1}$ sodium bicarbonate addition), indicating that more electrons are lost and not used for denitrification at high additions of bicarbonate. Noteworthy, the high Coulombic efficiency observed at all times indicates that the amount of electrons used for nitrate reduction closely match the amount of electrons provided electrochemically. Thus, these high CE values strongly suggest that no organic matter was present in the system and the cathode was the sole electron donor for denitrification.

Although previous studies clearly indicated the dependency between buffer capacity and current generation in bioelectrochemical systems, to the best of our knowledge, this is the first study demonstrating a relationship between effective buffer capacity (as $\mathrm{H}^{+}$equivalents) and expected (calculated) current. However, because the method is based simply on medium characteristics, it assumes that microbial activity is not a limiting factor. Thus, achieving maximum removal rates will in practice depend on the preliminary biofilm growth/adaptation and other environmental conditions. Moreover, as clearly indicated 
in the experiments with variable flow rates, the effective current generated can be slightly higher than predicted, resulting in a $\mathrm{pH}$ rise (Figure $1 \mathrm{a}$ ).

Testing the Effect of Mixing Conditions. As indicated in Figure $3 \mathrm{~b}$, the cathode region poses the highest pseudo-Ohmic

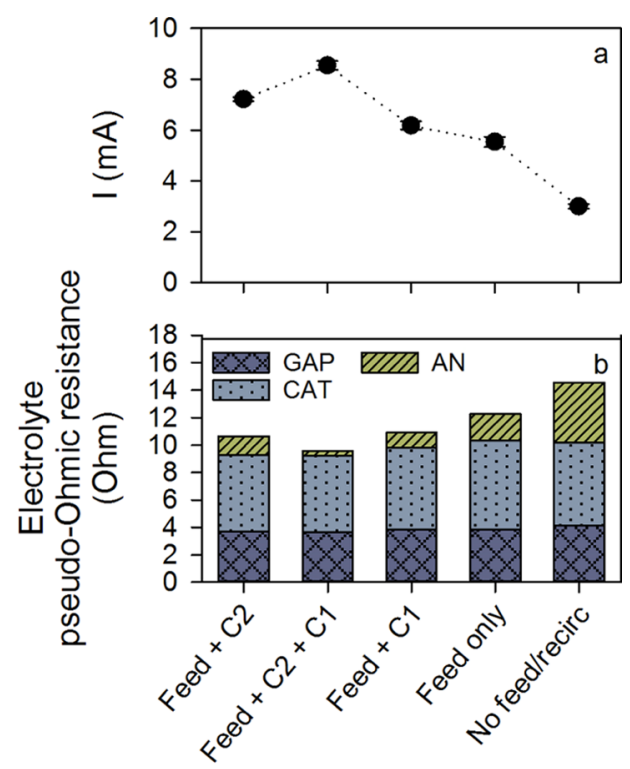

\section{Mixing condition}

Figure 3. Electrochemical behavior of the reactor at different mixing conditions during test 3. (a) Current generation $(\mathrm{mA}, n=3)$ and (b) electrolyte's pseudo-Ohmic resistance $(\mathrm{Ohm})$ of different regions of the reactor: anodic, cathodic, and gap (cathode $\times$ anode) sections.

resistance of the system $(5.9 \pm 0.4 \Omega)$, despite its depth being only $5 \mathrm{~cm}$ as opposed to $7 \mathrm{~cm}$ for both gap $(3.8 \pm 0.2 \Omega)$ and anode bed $(1.8 \pm 1.5 \Omega)$. Although cathodic and gap resistance are relatively constant throughout the experimental conditions, the anodic resistance is greatly reduced when the anodic recirculation starts (phase 2). Despite anodic recirculation being also included in phase 3 , the anodic resistance increased slightly. However, in phases 4 and 5, the anodic resistance was greatly increased in the absence of anodic recirculation and feed, respectively.

The flux of ions between the electrodes in electrochemical systems is driven by (1) diffusion (due to activity gradient), (2) migration (due to an electrostatic potential gradient dependent on electrolyte resistivity) and (3) convection (due to fluid flow/agitation). ${ }^{28}$ However, considering that ions' concentrations in the bulk solution are high enough, then the flux of ions through the diffusion in BES can be considered negligible. Moreover, the relatively constant cathodic and gap resistance with different mixing conditions in our study indicates the true Ohmic nature of the charge transfer, whereby the ions' flux is driven mainly by migration processes (Figure 3). Noteworthy, the migration of ions is directly correlated to ionic conductivity (and inversely correlated to Ohmic resistance). Thus, considering that a seawater medium containing $35 \mathrm{~g} \mathrm{~L}^{-1}$ sea salts presents conductivity sufficiently high to enable efficient migration ion transport, it is understandable that no further reduction in electrolyte resistance will occur by applying the recirculation circuits. Therefore, although the recirculation circuit 2 around the cathodic region clearly improves current generation (Figure 3a), the constant Ohmic resistance indicates that convection did not play a role in ion transport within the cathodic region and increased performance is attributed to improved mass transfer or flow distribution within the cathode rather than convective charge flow.

Similarly, the pseudo-Ohmic resistance is not affected by mixing within the gap section when activating recirculation circuit 1 , which would represent an important factor for reactor up scaling. In fact, small Ohmic losses across the liquid phase due to high salinity would enable a reduction in cell voltage or use of bigger electrodes surface area with minimal losses.

Contrary to a purely migration-driven process, a decrease in pseudo-Ohmic resistance at the anodic region is observed when recirculation circuit 1 is introduced, indicating the presence of a non-Ohmic behavior. The improvement in current generation with recirculation circuit 1 is attributed to the removal of gas bubbles formed at the anode (i.e., oxygen gas), which prevent contact between the electrode surface and the liquid phase, thus inactivating part of the anode. Those results confirm the importance of convection processes through anodic recirculation to the system, which facilitates mass transport and gas dispersion within the anode. This behavior did not occur at the cathode likely due to the cathode setup in which the granules were occupying the whole reactor's cross section, forcing the water to flow through (i.e., avoiding preferential flow) and likely removing the $\mathrm{N}_{2}$ bubbles.

Considerations toward Application of the Technology. Considering the saltwater medium containing $1 \mathrm{~g} \mathrm{~L}^{-1}$ $\mathrm{NaHCO}_{3}(11.9 \mathrm{mM})$, approximately $7.3 \%$ of this bicarbonate is present (at $\mathrm{pH}$ 7) as $\mathrm{CO}_{2} /$ carbonic acid, working as buffer. This corresponds to a concentration of approximately $38 \mathrm{mg}$ $\mathrm{L}^{-1} \mathrm{CO}_{2}$, which is 2.6 times higher than the $15 \mathrm{mg} \mathrm{L}^{-1} \mathrm{CO}_{2}$ $(0.34 \mathrm{mM})$ suggested for aquaculture waters. ${ }^{9}$ However, this added $11.9 \mathrm{mM}$ bicarbonate is not enough to maintain the $\mathrm{pH}$ balance within the cathodic denitrifying biofilm. Thus, the $\mathrm{pH}$ dependent buffer capacity of aquaculture waters might limit cathodic denitrification and further addition of bicarbonate may not be recommended, as it will likely increase the $\mathrm{CO}_{2}$ levels to concentrations higher than acceptable for fish production. Although previous studies reported that denitrification reactions in bioelectrochemical systems require a $\mathrm{pH}$ between 6.0 and $6.5{ }^{25}$ which can increase proton availability via the $\mathrm{CO}_{2}$ /bicarbonate system, reducing the $\mathrm{pH}$ to such low levels could become impractical for the treatment of saltwater aquaculture streams, which commonly have $\mathrm{pH}$ higher than 8.0. ${ }^{29,30}$ However, most recirculating aquaculture systems do have an operating nitrifying treatment step, ${ }^{31,32}$ which intrinsically reduces the $\mathrm{pH}$ and alkalinity of the water during ammonium oxidation to nitrate..$^{33,34}$ Noteworthy, the stoichiometry of autotrophic nitrification indicates that two protons are produced for each $\mathrm{NH}_{4}^{+}$oxidized to $\mathrm{NO}_{3}^{-}$. Thus, those protons can theoretically provide one third of the protons required for the reduction of nitrate to dinitrogen gas (six protons $/ \mathrm{NO}_{3}{ }^{-}$). Moreover, alkalinity and buffer capacity of the recirculating water can be restored if a denitrification step is installed after the nitrification filter, which potentially enables a reduction of bicarbonate addition commonly done in aquaculture for alkalinity restoration. ${ }^{34}$ Moreover, it is hypothesized that a slightly higher overall recirculation level of the aquaculture stream through the denitrifying reactor would enable low nitrate levels that are well matched with the buffer capacity of the recirculating water.

The overall energy consumption (test 1) for nitrogen removal via denitrification $\left(27 \pm 6 \mathrm{kWh} \mathrm{kg} \mathrm{N}^{-1}\right)$ varies 


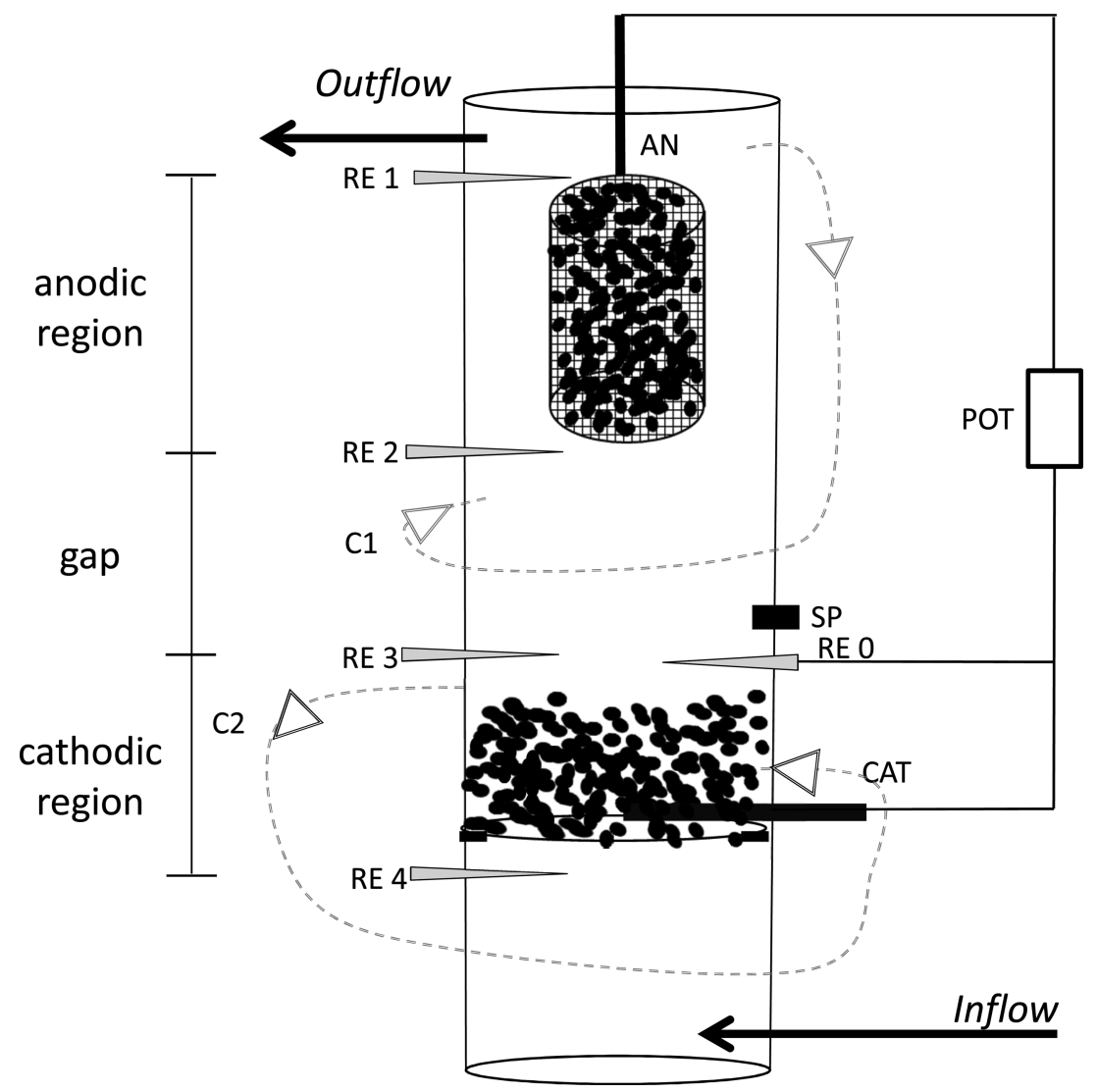

Figure 4. Setup of BES reactor used for the experiments. AN: anode; CAT: cathode; $\mathrm{RE}_{0}$ : reference electrode connected to the potentiostat, controlling the system via the three-electrode setup; $\mathrm{RE}_{1}-\mathrm{RE}_{4}$ : independent reference electrodes 1-4; $\mathrm{C} 1$ and $\mathrm{C} 2$ : recirculation circuits 1 and 2, respectively; SP: liquid sampling port.

according to cell voltage, especially when fast flow rates are applied (Figure 1d). Although lowest cell voltages are obtained at $0.5 \mathrm{~L} \mathrm{day}^{-1}$, a lower nitrogen removal per operation time is observed, which raises the specific energy consumption at this flow rate. Although this energy consumption represents operational costs that are currently twice as high as those for the operation of sand filters (Supporting Information 3), the standard costs for aeration of aquaculture fish tanks could be at least partially offset by taking into account the production of oxygen at the anode. Based purely on the calculations that take into account the generated current, if produced, oxygen concentrations at the effluent of the BES could achieve levels-at the exit of the bioelectrochemical denitrification reactor-ranging from $16.4 \mathrm{mg} \mathrm{O}_{2} \mathrm{~L}^{-1}$ at $3 \mathrm{~L} \mathrm{day}^{-1}$ to concentrations above the oxygen saturation at $1 \mathrm{~atm}$. Since producing dissolved oxygen above the saturation concentration is not feasible in practice, one could suggest a recirculation around the anode to include a circuit straight from the fish tank, thus diluting the generated oxygen in the water column of the fish tanks. However, further studies are still necessary to improve oxygen diffusion from the anode, especially at such high (calculated) oxygen production rates.

Due to the novelty in performing autotrophic cathodic denitrification of saltwater streams in BES, microbial community structure assessment via $16 \mathrm{~S}$ rRNA gene amplicon sequencing is presented in the Supporting Information 4, describing the community composition and indicating the main drivers of the denitrification process in our study. At this stage, this study comprises a proof of concept, indicating the applicability of the bioelectrochemical denitrification as a valid alternative to heterotrophic denitrification and simultaneous reoxygenation in saltwater aquaculture streams. The system showed minimum ammonium and nitrite accumulation, simultaneously achieving negligible production of $\mathrm{Cl}_{2}$ despite the high salt concentration of the synthetic media. However, further improvements are suggested to enhance the reactor's performance and decrease the capital and operational costs before full-scale implementation, which includes increasing nitrate removal rates and minimizing the size of the other electrochemical components, especially the size of the anode.

\section{MATERIAL AND METHODS}

Reactor Setup. A single-chamber cylindrical reactor with 1 $\mathrm{L}$ total volume capacity $(6 \mathrm{~cm}$ internal diameter $)$ was used for the experiments (Figure 4). Graphite granules (EC-100, Minus $3 / 8$ inch by 10 U.S. Standard Mesh- $10 \mathrm{~mm} \times 2 \mathrm{~mm}$, Graphite Sales, Inc.) were used as both anode and cathode materials. External connection was guaranteed by inserting a graphite rod (National CMG rods 74-5671-00 3/16 × 12) in both electrodes. The cathode bed $(5 \mathrm{~cm}$ depth) had a volume of approximately $160 \mathrm{~mL}(80 \mathrm{~mL}$ net cathodic volume (NCV), corresponding to the liquid volume held within the cathodic graphite granular bed). Cathodic granules were placed on top of a perforated acrylic plate as a supporting material, with a gap of $6 \mathrm{~cm}$ from the bottom of the reactor to allow for uniform water distribution through the cathode bed. Anodic granules (abiotically operated) were contained in a basket made of inert plastic mesh $(7 \mathrm{~cm}$ deep $\times 3 \mathrm{~cm}$ diameter, totaling $44 \mathrm{~mL}$ net anode volume) and inserted through the top of the reactor, 
with an anode-cathode gap, that is, the distance between the top of the cathode and the bottom of the anode, of $7 \mathrm{~cm}$. No membrane was used between anode and cathode. Media recirculation was initially done within the cathode to avoid flow channeling and mass transfer limitations (electrolyte recirculated from the top portion of the cathode, back to its lower portion at a flow rate of approximately $9 \mathrm{~L} \mathrm{~h}^{-1}$ ), except when stated otherwise. A reference electrode called $\mathrm{RE}_{0}(\mathrm{Ag} / \mathrm{AgCl}$, saturated $\mathrm{KCl}$, corresponding to $-0.197 \mathrm{~V}$ vs standard hydrogen electrode, SHE) was inserted above the cathode, enabling a three-electrode setup. To enable biologically mediated hydrogen production, ${ }^{35}$ while maximizing hydrogen uptake for denitrification (as noticed in preliminary studies done in our laboratory), the cathode potential was controlled at $-0.7 \mathrm{~V}$ vs SHE with the use of a potentiostat (VMP3, BioLogic, France). Unless otherwise stated, the electrochemical potentials are herein reported versus the SHE.

Reactor Operation and Monitoring. The reactor was enriched in continuous mode using freshwater synthetic media during preliminary operation (Supporting Information 1) and was shifted to saltwater operation by gradually increasing the salt concentration to $35 \mathrm{~g} \mathrm{~L}^{-1}$ sea salt (Ocean Nature Sea Salt, Aquasonic, Australia). During the adaptation, the reactor was then reinoculated with sediments taken from an intertidal mangrove environment (5-40 cm deep) in Southeast Queensland, Australia. Subsamples were taken throughout the whole depth of the collected core sample, mixed together, and suspended in artificial brackish water containing $25 \mathrm{~g} \mathrm{~L}^{-1}$ sea salt, $20 \mathrm{mg} \mathrm{L}^{-1} \mathrm{NO}_{3}{ }^{-}-\mathrm{N}, 1 \mathrm{~g} \mathrm{~L}^{-1} \mathrm{NaHCO}_{3}, 19.4 \mathrm{mg} \mathrm{L}{ }^{-1}$ $\mathrm{NaH}_{2} \mathrm{PO}_{4}, 3.84 \mathrm{mg} \mathrm{L}^{-1} \mathrm{NH}_{4} \mathrm{Cl}$, and trace elements solution as previously described. ${ }^{36}$ Although nitrate concentration in recirculating aquaculture systems can reach high levels $(>100$ $\mathrm{mg} \mathrm{L}^{-1}$ ), as previously mentioned, reduced levels are generally required for discharge purposes, especially in sensitive areas. In addition, considering that (1) low levels of nitrogen also contribute to a reduced growth of other (undesired) organisms within the water columns and (2) intrinsic buffer capacity provided by the naturally occurring bicarbonate system in the fish tanks may only allow for the reduction of low nitrate amounts, the authors propose herein that nitrogen levels should be always kept at low levels, thus justifying the addition of only $20 \mathrm{mg} \mathrm{L}^{-1} \mathrm{NO}_{3}{ }^{-}-\mathrm{N}$ in the feed. The $\mathrm{pH}$ of the medium was adjusted to 6.9 by adding $\mathrm{HCl} 1 \mathrm{M}$. The suspended material was then allowed to settle overnight at $3{ }^{\circ} \mathrm{C}$. After this step (considering that microbial cells would deposit on the upper layer of the settled material), only the supernatant and the upper layer were collected, whereas the heavier solids (possibly containing large amounts of biodegradable particles) were discarded. The collected supernatant was centrifuged at 12000 $\mathrm{rpm}$ for $10 \mathrm{~min}$. In this stage, the supernatant fraction of the centrifuged material was then discarded (removing the dissolved organic matter), whereas the fine sediment fraction was resuspended in $10 \mathrm{~mL}$ synthetic brackish water and inserted in the reactor through a port within the mid portion of the cathodic bed.

The synthetic seawater aquaculture medium used for the experiments was the same brackish water medium described above, except for a higher sea salt concentration $\left(35 \mathrm{~g} \mathrm{~L}^{-1}\right)$. The medium was fed continuously from the bottom of the reactor, flowing first through cathodic zone and then toward anodic zone at $3 \mathrm{~L} \mathrm{day}^{-1}$, unless stated otherwise. Noteworthy, the use of the synthetic solutions in this study enabled the assessment of fundamental research questions and the proof of concept, which required strictly controlled experimental conditions (i.e., known concentration of major ions and stable influent characteristics).

The reactor's performance was evaluated through electrochemical measurements and by analyzing the liquid samples taken above the cathodic zone-which warrants the characterization of the denitrification products right after the media has passed through the cathodic zone. The liquid samples were filtered through a $0.22 \mu \mathrm{m}$ membrane filter (Merck). Dissolved nitrogen species $\left(\mathrm{NO}_{3}{ }^{-}-\mathrm{N}, \mathrm{NO}_{2}{ }^{-}-\mathrm{N}\right.$, and $\left.\mathrm{NH}_{4}{ }^{+}-\mathrm{N}\right)$ were analyzed via Flow Injection Analyser (Lachat QuikChem8000, Lachat Instruments, Milwaukee) and greenhouse gases nitrous oxide $\left(\mathrm{N}_{2} \mathrm{O}\right)$ and methane $\left(\mathrm{CH}_{4}\right)$ were analyzed as previously described for liquid samples. ${ }^{37}$ Nitric oxide (NO), formed as an intermediate step during denitrification, is usually consumed at fast rates; its accumulation was assumed negligible in our system, hence it was not measured. ${ }^{16,38,39}$ Dissolved oxygen (DO) and $\mathrm{Cl}_{2}$ were measured after anodic zone using a DO probe (SevenGo pro, Mettler Toledo International) and Free Chlorine colorimetric method (USEPA DPD method 8021, $\mathrm{HACH}$ ), respectively.

The cell voltage and energy consumption were recorded at all times by the potentiostat. Four additional (independent) reference electrodes not connected a potentiostat $\left(\mathrm{RE}_{1-4}\right)$ were also inserted at different levels in the water column. By connecting these electrodes to a multimeter (Fluke 179 True RMS), it was possible to determine the effective anode potentials $\left(E_{\mathrm{an}}\right.$, which was a function of cell voltage, depending on cathodic requirements), as well as the liquid potential losses.

Experiments. The following experimental sequence was developed to evaluate individually the effects of influent flow rate, added bicarbonate concentration, and mixing conditions. The tests were done after 135 days of reactor operation.

Test 1: Flow Rate and Hydraulic Retention Time (HRT) Variation. To determine the effects of different nitrate and buffer loading rates on current production and $\mathrm{N}$-products profile, a series of feed flow rates and hence hydraulic retention times were tested. Starting from the fastest feed rate (which indirectly enabled higher buffer loads to pass through the cathode), the flow rate was decreased on a daily basis $(3,2,1$, and $0.5 \mathrm{~L} \mathrm{day}^{-1}$, corresponding to cathodic HRT of approximately $40,60,120$, and $240 \mathrm{~min}$ respectively), followed again by stepwise daily increase in the flow rate to test the reproducibility of the results. During test 1 , recirculation was applied within the cathode (recirculation circuit 2) only to avoid mass transfer limitations. Liquid samples were taken twice at each condition (approximately 16 and $24 \mathrm{~h}$ after setting up a new flow rate).

Test 2: Bicarbonate Concentration. Based on previous work on microbial anodes and cathodes, ${ }^{40,41}$ it is hypothesized that the electron transfer rate at the cathode is controlled not by the nitrate loading but by the supply rate of $\mathrm{pH}$ buffers. The following set of tests was done to understand the effects of different buffer concentrations and assess whether higher buffer concentrations could improve current generation and denitrification rates. The role of buffer capacity provided by bicarbonate system was evaluated by adding 1,2 , 4, and $6 \mathrm{~g} \mathrm{~L}^{-1}$ sodium bicarbonate, leading to the final concentrations of 14.3 , 26.2, 50.0, and $73.8 \mathrm{mM}$ respectively (which includes $2.3 \mathrm{mM}$ bicarbonate present in the commercial sea salt added). Thus, the procedure theoretically increased the buffer capacity at a fixed flow rate of $3 \mathrm{~L} \mathrm{day}^{-1}$ and influent $\mathrm{pH} 7.1 \pm 0.2$. Recirculation within the cathode was kept at all times to avoid 
mass transfer limitations. Considering a $20 \%$ nitrate removal efficiency obtained in preliminary tests at a low buffer capacity, and assuming that the removal rate may increase linearly with the added sodium bicarbonate, one could assume that nitrate would be completely removed if more than $5 \mathrm{~g} \mathrm{~L}^{-1}$ sodium bicarbonate is added. Therefore, to enable the tests at high bicarbonate concentrations to be carried out also in the presence of nitrate (thus enabling the determination of the removal rates), the feed nitrate concentration $\left(20 \mathrm{mg} \mathrm{L}^{-1}\right.$ $\mathrm{NO}_{3}{ }^{-}-\mathrm{N}$ when testing 1 and $2 \mathrm{~g} \mathrm{~L}^{-1}$ sodium bicarbonate) was increased to $40 \mathrm{mg} \mathrm{L}^{-1} \mathrm{NO}_{3}^{-}-\mathrm{N}$ when testing 4 and $6 \mathrm{~g} \mathrm{~L}^{-1}$ sodium bicarbonate.

The added sodium bicarbonate is expected to dissociate in solution as follows

$$
\begin{aligned}
& \mathrm{CO}_{2}+\mathrm{H}_{2} \mathrm{O} \leftrightarrow \mathrm{H}_{2} \mathrm{CO}_{3} \leftrightarrow \mathrm{HCO}_{3}{ }^{-}+\mathrm{H}^{+} \\
& \mathrm{HCO}_{3}{ }^{-} \leftrightarrow \mathrm{CO}_{3}^{2-}+\mathrm{H}^{+}
\end{aligned}
$$

In ideal (standard) conditions, $\mathrm{p} K_{\mathrm{a} 1}$ and $\mathrm{p} K_{\mathrm{a} 2}$ values of bicarbonate system (i.e., 6.4 and 10.2, respectively) dictate the relative amount of each dissociated form, depending on the actual $\mathrm{pH}$ of the solution. If the solution has a neutral $\mathrm{pH}$ close to $\mathrm{p} K_{\mathrm{a} 1}$, it is expected that approximately $50 \%$ of the added sodium bicarbonate will dissociate into carbonic acid $\left(\mathrm{CO}_{2} /\right.$ $\left.\mathrm{H}_{2} \mathrm{CO}_{3}\right)$ and $50 \%$ into bicarbonate $\left(\mathrm{HCO}_{3}^{-}\right)$, whereas negligible $\mathrm{CO}_{3}{ }^{2-}$ will be present. The effective buffer capacity is therefore considered to be the concentration of protons ( $\mathrm{mM}$ $\mathrm{H}^{+}$) that can potentially be yielded during the conversion of $\mathrm{H}_{2} \mathrm{CO}_{3}$ to $\mathrm{HCO}_{3}{ }^{-}$. At higher $\mathrm{pH}$ values that are closer to $\mathrm{p} K_{\mathrm{a} 2}$ (as it may occur at the exit of cathode zone due to denitrification activity), part of $\mathrm{HCO}_{3}{ }^{-}$can also loose protons and be further converted to $\mathrm{CO}_{3}{ }^{2-}$, providing additional buffer capacity at a higher $\mathrm{pH}$.

However, in real conditions, the effective buffer capacity of bicarbonate system may be affected by the presence of other ions. As previously reviewed by Batstone et al., ${ }^{42}$ nonideal behavior of physicochemical processes such as ion pairing and speciation can significantly influence wastewater treatment (i.e., interfering on precipitation $)^{43}$ and should be considered. Therefore, because the media used in this set of experiments contained high ionic strength characteristic of seawater $(>0.6$ $\mathrm{M})$, bicarbonate speciation and medium effective buffer capacity was assessed by using the Minteq software (Visual MINTEQ 3.1, J.P. Gustafsson, Sweden), using the DebyeHückel method for activity correction. As input parameters, the total concentration of most important ions in the medium (>0.05 mM) was considered, calculated as the sum of ions provided by both seasalt and added ions (according to the described media composition) at the measured inflow and outflow $\mathrm{pH}$. At $1 \mathrm{~g} \mathrm{~L}^{-1}$ added $\mathrm{NaHCO}_{3}$, the ion concentrations were as follows: $544.2 \mathrm{mM} \mathrm{Cl}^{-}, 28.2 \mathrm{mM} \mathrm{SO}_{4}{ }^{2-}, 480.2 \mathrm{mM}$ $\mathrm{Na}^{+}, 52.8 \mathrm{mM} \mathrm{Mg}^{2+}, 14.3 \mathrm{mM} \mathrm{CO}_{3}{ }^{2-}, 10.2 \mathrm{mM} \mathrm{Ca}^{2+}, 10.2 \mathrm{mM}$ $\mathrm{K}^{+}, 1.41 \mathrm{mM} \mathrm{NO}_{3}{ }^{-}, 0.3 \mathrm{mM} \mathrm{Br}^{-}, 0.16 \mathrm{mM} \mathrm{PO}_{4}{ }^{3-}, 0.09 \mathrm{mM}$ $\mathrm{Sr}^{2+}$, and $0.07 \mathrm{mM} \mathrm{NH}_{4}^{+}$.

Test 3: Mixing Conditions. To investigate whether convection plays a role on ion transfer between cathode and anode, we checked whether current generation and potential losses across liquid phase (within cathodic, anodic, and gap sections) are affected by mixing conditions. A series of recirculating/feeding conditions were tested as a different combination of presence/absence of feed $\left(3 \mathrm{~L} \mathrm{day}^{-1}\right)$ and recirculation circuits $\mathrm{C} 1\left(9 \mathrm{~L} \mathrm{~h}^{-1}\right)$-within both anode and gap sections-and $\mathrm{C} 2\left(9 \mathrm{~L} \mathrm{~h}^{-1}\right)$-within cathodic section only
(Figure 4). The different tests included: phase 1: feed $+\mathrm{C} 2$; phase 2, full recirculation: feed $+\mathrm{C} 1+\mathrm{C} 2$; phase 3 : feed $+\mathrm{C} 1$; phase 4: feed only; and phase 5: no feed/recirculation. Each condition was kept for at least $3 \mathrm{~h}$, allowing cathodic media to be completely replaced ( $>3$ cathodic HRTs) before measuring the Ohmic potential losses across liquid phase-except for phase 5, which was carried out in the absence of feed. Voltage losses across the liquid phase were measured through four additional (independent) reference electrodes, placed $\left(\mathrm{RE}_{1}\right)$ on top of anode, $\left(\mathrm{RE}_{2}\right)$, below anode, $\left(\mathrm{RE}_{3}\right)$, just above cathode bed, and $\left(\mathrm{RE}_{4}\right)$ below cathode bed. Those independent electrodes allowed for the measurement of potential losses across different portions of the reactor: cathode, anode, and gap (Figure 4).

Calculations. Cathodic Coulombic efficiency was calculated as

$$
\begin{aligned}
& \mathrm{CE}(\%)=\left\{\left(\left[5\left(-\Delta \mathrm{NO}_{3}{ }^{-}-\mathrm{N}\right)-3\left(\Delta \mathrm{NO}_{2}{ }^{-}-\mathrm{N}\right)-\left(\Delta \mathrm{N}_{2} \mathrm{O}-\mathrm{N}\right)\right.\right.\right. \\
& \left.\left.\left.+3\left(\Delta \mathrm{NH}_{4}{ }^{+}-\mathrm{N}\right)\right] \times V \times F\right) /(M \times C)\right\} \times 100
\end{aligned}
$$

where $M=14 \mathrm{mg}$ per $\mathrm{mmol}^{-1}$ is the nitrogen molecular weight; $V(\mathrm{~L})$ is the liquid volume of the cathodic region; $\Delta \mathrm{NO}_{3}{ }^{-}-\mathrm{N}$, $\Delta \mathrm{NO}_{2}{ }^{-}-\mathrm{N}, \Delta \mathrm{N}_{2} \mathrm{O}-\mathrm{N}$, and $\Delta \mathrm{NH}_{4}{ }^{+}-\mathrm{N}\left(\mathrm{mg} \mathrm{N} \mathrm{L}^{-1}\right)$ are the differences of nitrogen concentrations between outflow and inflow; $C$ (Coulombs) is the cumulative electric charge transferred through the duration of the experiment (set to 1 HRT); and $F$ is the Faraday constant (96485 C per mol e ${ }^{-}$). As previously demonstrated, nitric oxide accumulation is assumed to be negligible. ${ }^{16,38,39}$ Moreover, as demonstrated in the above equation, electron losses due to uptake via dissimilatory nitrate reduction to ammonium were considered.

The energy consumption was calculated as described elsewhere. ${ }^{44}$ Potential losses across liquid phase in anodic, gap, and cathodic regions were calculated as $\Delta E_{\mathrm{an}}=\mathrm{RE}_{1}-\mathrm{RE}_{2}$, $\Delta E_{\text {gap }}=\mathrm{RE}_{2}-\mathrm{RE}_{3}, \Delta E_{\text {cat }}=\mathrm{RE}_{3}-\mathrm{RE}_{4}$, where $\Delta E$ is the electrolyte's Ohmic drop measured between two reference electrodes (RE). Pseudo-Ohmic resistance $\left(\mathrm{PR}_{\Omega}\right)$ across different regions of the reactor were then calculated according to Ohms's law $\left(\mathrm{PR}_{\Omega}=\Delta E \times I^{-1}\right)$, where $\mathrm{PR}(\Omega)$ is the electrolyte's resistance of each region and $I$ is the current (A) flowing through the device. The use of the term pseudo-Ohmic resistance herein acknowledges that the overall resistance across the electrolyte might be lower than the Ohmic resistance itself if convection significantly contributes to ion transfer.

Moreover, considering 1 proton available per $\mathrm{CO}_{2}$ in the influent medium and 1 proton yielded per $\mathrm{CO}_{3}{ }^{2-}$ formed in effluent medium, the maximum theoretical current based on buffer capacity can be calculated as

$$
I(\mathrm{~mA})=\frac{Q \times\left(\mathrm{CO}_{2 \text { in }}+\mathrm{CO}_{3}{ }^{2-}{ }_{\text {out }}\right) \times n \times F}{86400}
$$

where $Q$ is the influent flow rate $\left(\mathrm{L} \mathrm{day}^{-1}\right), \mathrm{CO}_{2}$ in $(\mathrm{mM})$ is the concentration of $\mathrm{CO}_{2} / \mathrm{H}_{2} \mathrm{CO}_{3}$ acid form in the prepared media (given by Minteq simulation, considering influent $\mathrm{pH}$ ), $\mathrm{CO}_{3}{ }^{2-}$ out $(\mathrm{mM})$ is the concentration of $\mathrm{CO}_{3}{ }^{2-}$ basic form present at the exit from cathode (given by Minteq simulation, considering effluent $\mathrm{pH}), n$ is the amount of electrons required for the reduction of each proton ( 1 electron/proton), and 86 400 is the time conversion factor.

Values of nitrate removal rates via complete denitrification provided herein are normalized to NCV, unless stated otherwise. 


\section{ASSOCIATED CONTENT}

\section{S Supporting Information}

The Supporting Information is available free of charge on the ACS Publications website at DOI: 10.1021/acsomega.8b00287.

Preliminary reactor operation (Text S1); ANOVA flow rates (Text S2); operational costs (BES versus sandfilters) (Text S3); and assessment of the saltwater adapted cathodic microbial community composition (Text S4) are provided (PDF).

\section{AUTHOR INFORMATION}

\section{Corresponding Author}

*E-mail: s.freguia@awmc.uq.edu.au.

ORCID

Elisa Marx Sander: 0000-0001-5992-138X

Notes

The authors declare no competing financial interest.

\section{ACKNOWLEDGMENTS}

This research was supported by the Australian Research Council (Grants DP160102308 and LP150100402).

\section{REFERENCES}

(1) Avnimelech, Y. Carbon/nitrogen ratio as a control element in aquaculture systems. Aquaculture 1999, 176, 227-235.

(2) Endut, A.; Jusoh, A.; Ali, N. A. Nitrogen budget and effluent nitrogen components in aquaponics recirculation system. Desalin. Water Treat. 2014, 52, 744-752.

(3) Lemonnier, H.; Faninoz, S. Effect of water exchange on effluent and sediment characteristics and on partial nitrogen budget in semiintensive shrimp ponds in New Caledonia. Aquacult. Res. 2006, 37, 938-948.

(4) Sandu, S.; Hallerman, E. Biodegradation of Nitrogen in a Commercial Recirculating Aquaculture Facility. In Biodegradation Engineering and Technology; Chamy, R., Ed.; IntechOpen: London, 2013; pp 341-364.

(5) Schuler, D. J.; Boardman, G. D.; Kuhn, D. D.; Flick, G. J. Acute Toxicity of Ammonia and Nitrite to Pacific White Shrimp, Litopenaeus vannamei, at Low Salinities. J. World Aquacult. Soc. 2010, 41, 438-446.

(6) Honda, H.; Watanabe, Y.; Kikuchi, K.; Iwata, N.; Takeda, S.; Uemoto, H.; Furuta, T.; Kiyono, M. High Density Rearing of Japanese Flounder, Paralichthys olivaceus with a Closed Seawater Recirculation System Equipped with a Denitrification Unit. Aquacult. Sci. 1993, 41, $19-26$.

(7) van Bussel, C. G. J.; Schroeder, J. P.; Wuertz, S.; Schulz, C. The chronic effect of nitrate on production performance and health status of juvenile turbot (Psetta maxima). Aquaculture 2012, 326-329, 163167.

(8) Tsai, S. J.; Chen, J. C. Acute toxicity of nitrate on Penaeus monodon juveniles at different salinity levels. Aquaculture 2002, 213, 163-170.

(9) Australian and New Zealand Environment and Conservation Council and the Agriculture and Resource Management Council of Australia and New Zealand. Australian and New Zealand Guidelines for Fresh and Marine Water Quality. In National Water Quality Management Strategy; Australian and New Zealand Environment and Conservation Council and the Agriculture and Resource Management Council of Australia and New Zealand: Camberra, 2000; Vol. 1.

(10) Martins, C. I. M.; Eding, E. H.; Verdegem, M. C. J.; Heinsbroek, L. T. N.; Schneider, O.; Blancheton, J. P.; d'Orbcastel, E. R.; Verreth, J. A. J. New developments in recirculating aquaculture systems in Europe: A perspective on environmental sustainability. Aquacult. Eng. 2010, 43, 83-93.
(11) Tsukuda, S.; Christianson, L.; Kolb, A.; Saito, K.; Summerfelt, S. Heterotrophic denitrification of aquaculture effluent using fluidized sand biofilters. Aquacult. Eng. 2015, 64, 49-59.

(12) Szekeres, S.; Kiss, I.; Bejerano, T. T.; Soares, M. I. M. Hydrogen-dependent denitrification in a two-reactor bio-electrochemical system. Water Res. 2001, 35, 715-719.

(13) Kurt, M.; Dunn, I. J.; Bourne, J. R. Biological denitrification of drinking water using autotrophic organisms with $\mathrm{H}(2)$ in a fluidizedbed biofilm reactor. Biotechnol. Bioeng. 1987, 29, 493-501.

(14) Virdis, B.; Rabaey, K.; Yuan, Z.; Keller, J. Microbial fuel cells for simultaneous carbon and nitrogen removal. Water Res. 2008, 42, $3013-3024$

(15) Pous, N.; Puig, S.; Dolors Balaguer, M.; Colprim, J. Cathode potential and anode electron donor evaluation for a suitable treatment of nitrate-contaminated groundwater in bioelectrochemical systems. Chem. Eng. J. 2015, 263, 151-159.

(16) Puig, S.; Coma, M.; Desloover, J.; Boon, N.; Colprim, J.; Balaguer, M. D. Autotrophic Denitrification in Microbial Fuel Cells Treating Low Ionic Strength Waters. Environ. Sci. Technol. 2012, 46, 2309-2315.

(17) Pous, N.; Puig, S.; Coma, M.; Balaguer, M. D.; Colprim, J. Bioremediation of nitrate-polluted groundwater in a microbial fuel cell. J. Chem. Technol. Biotechnol. 2013, 88, 1690-1696.

(18) Clauwaert, P.; Rabaey, K.; Aelterman, P.; De Schamphelaire, L.; Pham, T. H.; Boeckx, P.; Boon, N.; Verstraete, W. Biological Denitrification in Microbial Fuel Cells. Environ. Sci. Technol. 2007, 41, 3354-3360.

(19) Nguyen, V. K.; Hong, S.; Park, Y.; Jo, K.; Lee, T. Autotrophic denitrification performance and bacterial community at biocathodes of bioelectrochemical systems with either abiotic or biotic anodes. $J$ Biosci. Bioeng. 2015, 119, 180-187.

(20) Pous, N.; Puig, S.; Coma, M.; Balaguer, M. D.; Colprim, J. Bioremediation of nitrate-polluted groundwater in a microbial fuel cell. J. Chem. Technol. Biotechnol. 2013, 88, 1690-1696.

(21) Pozo, G.; Jourdin, L.; Lu, Y.; Ledezma, P.; Keller, J.; Freguia, S. Methanobacterium enables high rate electricity-driven autotrophic sulfate reduction. RSC Adv. 2015, 5, 89368-89374.

(22) Madigan, M. T.; Brock, T. D. Brock Biology of Microorganisms, 12th ed.; Pearson Education: San Francisco, 2009; p 1061.

(23) Ibanez, J.; Hernandez-Esparza, M.; Doria-Serrano, C.; FregosoInfante, A.; Singh, M. Chemistry Fundamentals, Part A. In Environmental Chemistry: Fundamentals; Springer: New York, 2007; pp 11-42.

(24) Vilajeliu-Pons, A.; Puig, S.; Pous, N.; Salcedo-Dávila, I.; Bañeras, L.; Balaguer, M. D.; Colprim, J. Microbiome characterization of MFCs used for the treatment of swine manure. J. Hazard. Mater. 2015, 288, $60-68$.

(25) Li, J. T.; Zhang, S. H.; Hua, Y. M. Performance of denitrifying microbial fuel cell subjected to variation in $\mathrm{pH}, \mathrm{COD}$ concentration and external resistance. Water Sci. Technol. 2013, 68, 250-256.

(26) Ruiz, Y.; Baeza, J. A.; Guisasola, A. Enhanced Performance of Bioelectrochemical Hydrogen Production using a $\mathrm{pH}$ Control Strategy. ChemSusChem 2015, 8, 389-397.

(27) Ruiz, Y.; Baeza, J. A.; Guisasola, A. Microbial electrolysis cell performance using non-buffered and low conductivity wastewaters. Chem. Eng. J. 2016, 289, 341-348.

(28) Oliot, M.; Galier, S.; Roux de Balmann, H.; Bergel, A. Ion transport in microbial fuel cells: Key roles, theory and critical review. Appl. Energy 2016, 183, 1682-1704.

(29) Seemann, U. B.; Lorkowski, K.; Slater, M. J.; Buchholz, F.; Buck, B. H. Growth performance of Noble Crayfish Astacus astacus in recirculating aquaculture systems. Aquacult. Int. 2015, 23, 997-1012.

(30) Visvanathan, C.; Hung, N. Q.; Jegatheesan, V. Hydrogenotrophic denitrification of synthetic aquaculture wastewater using membrane bioreactor. Process Biochem. 2008, 43, 673-682.

(31) Díaz, V.; Ibáñez, R.; Gómez, P.; Urtiaga, A. M.; Ortiz, I. Kinetics of nitrogen compounds in a commercial marine Recirculating Aquaculture System. Aquacult. Eng. 2012, 50, 20-27. 
(32) Sesuk, T.; Powtongsook, S.; Nootong, K. Inorganic nitrogen control in a novel zero-water exchanged aquaculture system integrated with airlift-submerged fibrous nitrifying biofilters. Bioresour. Technol.

2009, 100, 2088-2094.

(33) You, S. J.; Ren, N. Q.; Zhao, Q. L.; Kiely, P. D.; Wang, J. Y.; Yang, F. L.; Fu, L.; Peng, L. Improving phosphate buffer-free cathode performance of microbial fuel cell based on biological nitrification. Biosens. Bioelectron. 2009, 24, 3698-3701.

(34) van Rijn, J. The potential for integrated biological treatment systems in recirculating fish culture-A review. Aquaculture 1996, 139, 181-201.

(35) Jourdin, L.; Freguia, S.; Donose, B. C.; Keller, J. Autotrophic hydrogen-producing biofilm growth sustained by a cathode as the sole electron and energy source. Bioelectrochemistry 2015, 102, 56-63.

(36) Lu, H.; Oehmen, A.; Virdis, B.; Keller, J.; Yuan, Z. Obtaining highly enriched cultures of Candidatus Accumulibacter phosphates through alternating carbon sources. Water Res. 2006, 40, 3838-3848.

(37) Sturm, K.; Keller-Lehmann, B.; Werner, U.; Raj Sharma, K.; Grinham, A. R.; Yuan, Z. Sampling considerations and assessment of Exetainer usage for measuring dissolved and gaseous methane and nitrous oxide in aquatic systems. Limnol. Oceanogr.: Methods 2015, 13, 375-390.

(38) Richardson, D.; Felgate, H.; Watmough, N.; Thomson, A.; Baggs, E. Mitigating release of the potent greenhouse gas $\mathrm{N}(2) \mathrm{O}$ from the nitrogen cycle-could enzymic regulation hold the key? Trends Biotechnol. 2009, 27, 388-97.

(39) Virdis, B.; Rabaey, K.; Yuan, Z.; Rozendal, R. A.; Keller, J. Electron Fluxes in a Microbial Fuel Cell Performing Carbon and Nitrogen Removal. Environ. Sci. Technol. 2009, 43, 5144-5149.

(40) Torres, C. I.; Kato Marcus, A.; Rittmann, B. E. Proton transport inside the biofilm limits electrical current generation by anoderespiring bacteria. Biotechnol. Bioeng. 2008, 100, 872-81.

(41) Pous, N.; Koch, C.; Vila-Rovira, A.; Balaguer, M. D.; Colprim, J.; Muhlenberg, J.; Muller, S.; Harnisch, F.; Puig, S. Monitoring and engineering reactor microbiomes of denitrifying bioelectrochemical systems. RSC Adv. 2015, 5, 68326-68333.

(42) Batstone, D. J.; Amerlinck, Y.; Ekama, G.; Goel, R.; Grau, P.; Johnson, B.; Kaya, I.; Steyer, J. P.; Tait, S.; Takacs, I.; Vanrolleghem, P. A.; Brouckaert, C. J.; Volcke, E. Towards a generalized physicochemical framework. Water Sci. Technol. 2012, 66, 1147-61.

(43) Tait, S.; Clarke, W. P.; Keller, J.; Batstone, D. J. Removal of sulfate from high-strength wastewater by crystallisation. Water Res. 2009, 43, 762-772.

(44) Saleem, M.; Chakrabarti, M. H.; Hasan, D. B. Electrochemical removal of nitrite in simulated aquaculture wastewater. Afr. J. Biotechnol. 2011, 10, 16566-16576. 